\title{
Sources of Resistance to Crenate Broomrape Among Species of Vicia
}

\author{
J. C. Sillero and M. T. Moreno, CIFA, Departamento Mejora y Agronomía, Apdo 3092, E-14080-Córdoba, Spain; \\ and D. Rubiales, Instituto de Agricultura Sostenible, CSIC, Apdo 4084, E-14080-Córdoba, Spain
}

\begin{abstract}
Sillero, J. C., Moreno, M. T., and Rubiales, D. 2005. Sources of resistance to crenate broomrape among species of Vicia. Plant Dis. 89:23-27.

Crenate broomrape is a parasitic weed that represents a major constraint for pulse and forage legume production in the Mediterranean and West Asia regions. Control strategies have centered around agronomic practices and the use of herbicides, although success has been marginal. Resistance breeding is hampered by scarcity of proper sources of resistance and of a reliable and practical screening procedure. A germ plasm collection of 208 accessions of vetch belonging to 42 Vicia spp. was screened for resistance to crenate broomrape under field conditions. High levels of resistance were found in several species. Resistance of selected accessions was confirmed by a low induction of broomrape seed germination in pot and in vitro experiments. This was followed by a scarce establishment of broomrape radicles in contact with host roots and a limited development of established tubercles. In addition, a hypersensitive-like necrosis occasionally was observed, but at low frequency.
\end{abstract}

Additional keywords: haustorium, Orobanche crenata

Crenate broomrape (Orobanche crenata Forsk.) is a holoparasitic weed that attacks legume crops, such as faba bean, lentil, pea, and vetch, but also affects a large number of wild legume species $(1,14)$. It has been a major constraint for legume production in the Mediterranean and East Asia regions since antiquity $(1,9)$. The problem is maintained by both the tradition of legume cultivation in these areas and the fact that $O$. crenata has a broad host range. The soil seed bank can increase rapidly, because a single broomrape plant can produce hundreds of thousands of seed that remain viable in the soil for many years and germinate only after stimulation by root exudates of the host. Germinating seed attach to the host roots through a haustorium, the feeding organ that connects to the conductive tissues of the host. The parasitic relationship starts as soon as the haustorium has developed and a physiological bridge between the vascular system of the host and of the parasite has formed.

Various control methods have been proposed, ranging from cultural practices such as hand weeding, solarization, trap and catch crops, delayed sowing dates, and crop rotations, to the use of chemical and

Corresponding author: J. C. Sillero

E-mail: josefa.sillero.ext@juntadeandalucia.es

Financial support was provided by projects INIASC97-005C2-1 and AGL2002-03248.

Accepted for publication 19 July 2004.

DOI: 10.1094/PD-89-0023

(C) 2005 The American Phytopathological Society biological control methods. However, no single method has provided satisfactory control $(9,14)$. Genetic resistance is the most economical and ecologically sound method of disease control, but little success has been achieved in breeding legumes for broomrape resistance due the scarcity of sources of resistance and the complex inheritance of those available so far $(1,11)$. Thus, there is a great need for development of resistant cultivars and for better understanding of inheritance of resistance.

Vetch species (Vicia spp.) are important forage legumes in the Mediterranean region, where broomrape is widely distributed. The use of common vetch for hay greatly increases seed dissemination of the parasite as a result of feed transportation between farms and the spreading of manure in fields. Some resistance to crenate broomrape has been reported in common vetch (2) and wild Vicia spp. (7,17); still, most Vicia spp. are highly susceptible to this parasitic weed. The objectives of this research were to identify sources of resistance to crenate broomrape in a collection of vetch accessions covering different species of the genus Vicia, and to elucidate the defense reactions.

\section{MATERIALS AND METHODS}

Preliminary screening. In all, 208 accessions of vetch belonging to 42 Vicia spp., other than faba bean (Vicia faba L.), were screened for resistance to broomrape under field conditions during the 1995-96 growing season. The accessions included in the study were not selected based on any preliminary hypothesis of the probability of resistance due to the origin of the spe- cies. These accessions, originating from all around the world, were provided by CIFA (Centro de Investigación y Formación Agraria, Córdoba, Spain), the United States Department of Agriculture-Agricultural Research Service (Pullman, WA), IPK (Institut für Pflanzengenetik und Kulturpflanzenforschung, Gatersleben, Germany), and CGN (Center for Genetic Resources, Wageningen, the Netherlands) germ plasm banks. The accessions were sown on 29 November 1995 at Córdoba at the CIFA Alameda del Obispo experimental station, in a field with a history of heavy and uniform infestation of $O$. crenata. Each accession was sown in a 1-m row (10 plants per row), surrounded by four rows, spaced $0.7 \mathrm{~m}$ apart, of the susceptible faba bean cv. Prothabon. Topogard $(15 \%$ terbutylazine $+35 \%$ terbutryne, $\mathrm{wt} / \mathrm{vol}$ ) was applied as a host preemergence herbicide. Postemergence herbicide treatment was avoided in order not to interfere with broomrape infection; therefore, hand weeding was done when required. When necessary, plots were sprinkler irrigated to ensure vigorous crop growth and maximum broomrape emergence. The final number of emerged broomrape plants per host plant was recorded at plant maturity. Additionally, plants in each row were dug up carefully and the number of nonemerged broomrape tubercles and shoots per plant was counted. Row counts for emerged and nonemerged broomrape were expressed as a percentage of the mean number of broomrape plants observed in the adjacent susceptible check.

Selection and testing of promising accessions. The 37 most resistant accessions were selected and further studied under field conditions for two seasons (1996-97 and 1997-98). The plots consisted of 1-m rows (10 plants per row) distributed in a randomized block design with three replications. The accessions were sown on 22 November 1996 and 2 December 1997. The faba bean cv. Prothabon was used as susceptible check, as described above. At crop maturity, the final number of emerged broomrape plants per host plant was recorded, and the numbers of nonemerged broomrape tubercles and shoots per plant were counted after the plants were dug up. As described above, data were expressed relative to the broomrape infection of the susceptible faba bean cultivar.

Growth-chamber study. Thirty-one of the most promising accessions were further studied in a pot experiment in a growth chamber at $20 \pm 2^{\circ} \mathrm{C}$, photoperiod 
$14 \mathrm{~h}$ of light and $10 \mathrm{~h}$ of dark, with light intensity of $140 \mu \mathrm{mol} / \mathrm{m}^{2} / \mathrm{s}$ at the leaf canopy. The faba bean cv. Prothabon and pea cv. Messire were included as susceptible checks. Five-day-old seedlings were transferred to 1-liter plastic pots filled with vermiculite previously mixed with $25 \mathrm{mg}$ of broomrape seed (approximately 8,000 seed). Each accession was represented by 12 pots, with one plant per pot. At plant maturity (from day 90 after sowing, depending on the species), the plants were extracted from the pots, the roots were gently washed in water, and the number of broomrape attachments per plant was counted. The broomrape attachments were classified according their stage of development (S), following the 1-to-7 scale of Ter Borg et al. (18), where S1 = small tubercle, 1 to $3 \mathrm{~mm}$; $\mathrm{S} 2=$ crown roots start to develop; $\mathrm{S} 3=$ bud $\leq 1 \mathrm{~cm}$; S4 = first development of spike below ground surface; S5 = emergence of spike; $\mathrm{S} 6$ = flowering; and S7 $=$ setting of seed.
Mini-rhizotrons study. Early stages of broomrape infection of nine resistant accessions were studied in petri dishes, as described by Rubiales et al. (12). Faba bean cv. Prothabon and pea cv. Messire were used as susceptible checks. Ten plants per accession were grown individually in 15-cm-diameter petri dishes (minirhizotrons) with $8 \mathrm{mg}$ of broomrape seed (approximately 2,500 seed) spread over a microfiber filter disc. Viability of the broomrape seed was previously determined by the 2,3,5 triphenyltetrazolium chloride (TTC) method (8) as 65\%. Germination data were corrected with this viability. The broomrape seed were conditioned for 10 days in the dark at $20^{\circ} \mathrm{C}$ before viability and petri dish tests. The rhizotrons were punctured to allow emergence of the germinating host seed, sealed with parafilm and wrapped in aluminum foil, then vertically stored in a growth chamber under the conditions indicated above. After 30 days of incubation, 500

Table 1. Levels of broomrape infection in vetch (Vicia spp.) in the field in 1995-96, expressed as the percentage of emerged broomrape shoots per plant relative to the susceptible check cv. Protabhon

\begin{tabular}{|c|c|c|c|}
\hline Vicia spp. & No. of accessions & Mean & Range $^{\mathrm{z}}$ \\
\hline V. amphicarpa & 1 & 0.0 & 0 \\
\hline V. angustifolia & 6 & 12.4 & $0-43$ \\
\hline V. articulata & 10 & 17.1 & $0-82$ \\
\hline V. benghalensis & 10 & 12.8 & $0-42$ \\
\hline V. bithynica & 3 & 3.6 & $0-86$ \\
\hline V. cordata & 5 & 54.2 & $0-118$ \\
\hline V. cracca & 3 & 53.6 & $0-160$ \\
\hline V. cuspidata & 1 & 0.0 & 0 \\
\hline V. dalmatica & 2 & 0.0 & 0 \\
\hline V. disperma & 2 & 14.3 & 9-19 \\
\hline V. ervilia & 9 & 27.6 & $0-57$ \\
\hline V. fulgens & 1 & 63.0 & 63 \\
\hline V. galilaea & 1 & 24.0 & 24 \\
\hline V. grandiflora & 5 & 4.2 & $0-13$ \\
\hline$V$. hirsuta & 9 & 2.3 & $0-13$ \\
\hline V. hybrida & 4 & 25.7 & $0-75$ \\
\hline V. hyrcanica & 2 & 12.1 & $0-24$ \\
\hline$V$. incisaeformis & 1 & 8.0 & 8 \\
\hline$V$. johannis & 5 & 50.6 & $20-103$ \\
\hline V. lathyroides & 4 & 12.0 & $0-38$ \\
\hline V. lutea & 9 & 14.5 & $0-61$ \\
\hline V. macrocarpa & 2 & 16.1 & $0-32$ \\
\hline V. megalotropis & 1 & 0.0 & 0 \\
\hline$V$. melanops & 3 & 6.3 & $0-19$ \\
\hline V. michauxii & 3 & 0.0 & 0 \\
\hline$V$. monantha & 6 & 54.4 & $0-117$ \\
\hline V. narbonensis & 12 & 41.7 & $0-103$ \\
\hline V. onbrychioides & 1 & 0.0 & 0 \\
\hline V. orobus & 1 & 0.0 & 0 \\
\hline V. palaestina & 3 & 16.0 & $0-28$ \\
\hline$V$. pannonica & 12 & 34.1 & $0-104$ \\
\hline$V \cdot$ peregrina & 7 & 0.0 & 0 \\
\hline V. sativa & 33 & 58.3 & $0-214$ \\
\hline V. segetalis & 1 & 16.0 & 16 \\
\hline V. sepium & 2 & 25.0 & 25 \\
\hline V. serratifolia & 2 & 34.4 & $0-69$ \\
\hline V. sicula & 1 & 74.3 & 74 \\
\hline V. striata & 1 & 27.0 & 27 \\
\hline V. tennifolia & 3 & 0.0 & 0 \\
\hline V. tetrasperma & 2 & 0.0 & 0 \\
\hline$V$. vicioides & 1 & 9.0 & 9 \\
\hline V. villosa & 18 & 33.6 & $0-131$ \\
\hline Susceptible check $V \cdot f a b a$ & $\ldots$ & $100(6.5)$ & $100(4.2-8.4)$ \\
\hline
\end{tabular}

${ }^{\mathrm{z}}$ Maximum and minimum percentage of emerged broomrape plants for each species, relative to the susceptible check, faba bean cv. Prothabon $(=100 \%)$. Real values for Prothabon in parentheses.

broomrape seed in close proximity $(<3$ $\mathrm{mm})$ to the host roots were examined in each petri dish under a stereoscope at $\times 30$ magnification. Percent seed germination was determined by counting the number of broomrape seed with an emerged radicle. Percent establishment was determined by counting the number of germinated broomrape seed that established contacts with the host root and formed tubercles. After 45 days of incubation, the number of broomrape attachments per host plant was recorded.

Statistical analysis. An analysis of variance (ANOVA) was conducted with accessions as a fixed factor for both emerged and total broomrape shoots. Interaction between genotype and year also was studied. In the pot and mini-rhizotron experiments, following ANOVA, the significance of mean differences among accessions was assessed using the Duncan test $(P<0.05)$ for number of broomrape attachments per plant, percentage of germination, and percentage of establishment. When the components of resistance were expressed as percentage, data were angular transformed $(\arcsin \sqrt{1 / x})$ prior to ANOVA. Pearson's linear correlation coefficients between field and pot experiments were calculated. SPSS for Windows was used (version 10.0; SPSS Inc, Chicago).

\section{RESULTS}

Preliminary screening. High to moderate levels of resistance were found in some species of Vicia (Table 1). The susceptible faba bean check was infected uniformly across the plot with emerged broomrape plants ranging from 4.2 to 8.4 shoots per faba bean plant. Broomrape infection on the 208 vetch accessions ranged from 0 to 7.3 , with an average of 1.1 emerged shoots per host plant compared with the susceptible faba bean check, with an average of 6.5 emerged broomrape shoots per plant. Digging up the plants allowed the counting of nonemerged attachments, which ranged from 0 to 45 , with an average of 5.3 nonemerged attachments per host plant. In the susceptible check, an average of 14.6 underground nonemerged broomrape attachments were formed.

Due to rainy winter weather, conditions were conductive to broomrape development and emergence during all test seasons (13). The cooler temperature during February 1996 made the $1995-96$ season the least favorable of the three.

Performance of selected accessions. The 37 most resistant accessions were selected on the basis of lack of broomrape emergence (Table 2) and low number of underground nonemerged attachments. As a result of the more favorable weather conditions for broomrape infection during the 1996-97 season, an average of 10.3 emerged broomrape plants per plant of the faba bean check was observed. In 199697, broomrape emergence occurred in 
some of the accessions, with a maximum as high as $20 \%$ of that of check. An average of 9.8 emerged broomrape plants per plant was found in the check during 199798, with a maximum broomrape emergence of $27 \%$ in $V$. villosa subsp. eriocarpa. Even when broomrape incidence was higher in these two seasons on some Vicia accessions, emergence remained relatively low (maximum of 19.9 and $26.8 \%$ of the check, respectively) and most of the attachments, when successfully formed, remained underground.

There was a high correlation between number of emerged and nonemerged broomrape shoots per plant ( $r$ values ranging from 0.7 to $0.8, P<0.001$ ) for each season. Levels of broomrape infection between seasons were highly correlated $(r$ values ranging from 0.7 to $1.0, P<0.001$ ), reflecting the stability of the resistance. This was confirmed by ANOVA because there was no year-accession interaction for the percentage of emerged broomrape shoots, although this interaction was sig- nificant for the percentage of underground attachments.

Growth-chamber study. The resistance of selected accessions was confirmed in the pot experiment (Table 3). The established broomrape plants were classified according to their developmental stage. In the faba bean and pea checks, 16.7 and 17.3 broomrape attachments per plant, respectively, were formed. Significantly fewer establishments were formed in all Vicia accessions $(P<0.05)$. In most of them, at plant maturity, the attachments remained in early developmental stages $(S<4)$. In five accessions (V-37 of $V$. peregrina, $\mathrm{V}-109$ of $V$. lutea, V-155 of $V$. benghalensis, V-259 of $V$. monantha, and V-284 of V. hybrida), the maximum development of the broomrape plants was a crown of roots (S2), but there was no bud development. Accessions V-9 of $V$. lutea, V-97 of V. melanops var. loiseani, V-128 of V. tetrasperma, V-194 of V. tennifolia, and V-233 of $V$. onbrychioides showed less than 0.5 buds, smaller than $1 \mathrm{~cm}$ (S3) per plant.
Total number of broomrape shoots per plant recorded in the pot experiment was highly correlated with the number of emerged and total broomrape shoots per plant in the field experiment during the three seasons ( $r=0.7$ to $0.9, P<0.001$ ).

Mini-rhizotron study. Restricted broomrape establishment was confirmed in the rhizotron experiment (Table 4). This minirhizotron method was appropriate for pea and vetch but did not work successfully for faba bean due to early darkening of roots, probably due to oxygen depletion (1). The darkening of faba bean roots allowed observations on broomrape seed germination but precluded later observations on broomrape attachment. Lower numbers of attachments per plant were formed in all the Vicia accessions (ranging from 0 to 16 attachments per plant) than in the pea susceptible check (26 attachments per plant). In this particular study, two distinct mechanisms of resistance were identified. The first one is a restricted induction of broomrape seed germination. The pea

Table 2. Relative number of broomrape infections per plant in accessions Vicia spp. observed in field experiments over three seasons ${ }^{\mathrm{Z}}$

\begin{tabular}{|c|c|c|c|c|c|c|c|c|c|}
\hline \multirow[b]{2}{*}{ Accession } & \multirow[b]{2}{*}{ Code } & \multirow[b]{2}{*}{ Species } & \multirow[b]{2}{*}{ Origin } & \multicolumn{2}{|c|}{ 1995-96 season } & \multicolumn{2}{|c|}{ 1996-97 season } & \multicolumn{2}{|c|}{ 1997-98 season } \\
\hline & & & & Emerged & Total & Emerged & Total & Emerged & Total \\
\hline $\mathrm{V}-138$ & VIC 590/74 & $\begin{array}{l}\text { Vicia angustifolia subsp. } \\
\text { angustifolia }\end{array}$ & Finland & 0.0 & 19.8 & 0.0 & 45.0 & 18.9 & 38.6 \\
\hline V-149 & VIC $887 / 80$ & $V$. articulata & Spain & 0.0 & 17.7 & 12.2 & 54.2 & 10.2 & 12.8 \\
\hline V-155 & VIC 301/89 & $V$. benghalensis & Sweden & 0.0 & 26.4 & 3.3 & 10.0 & 21.8 & 32.6 \\
\hline$V-162$ & VIC 469/77 & V. cordata & Greece & 0.0 & 0.0 & 9.6 & 40.2 & 2.3 & 3.1 \\
\hline V-163 & VIC 470/75 & V. cordata & Italy & 0.0 & 6.9 & 0.6 & 15.4 & 20.3 & 31.8 \\
\hline V-189 & VIC 17/81 & V. cracca var. cracca & Romania & 0.0 & 0.0 & 0.0 & 0.0 & 0.9 & 3.7 \\
\hline V-190 & VIC $19 / 82$ & V. cracca var. cracca & Sweden & 0.0 & 0.0 & 0.0 & 0.0 & 0.0 & 0.0 \\
\hline V-196 & VIC $38 / 87$ & V. dalmatica & Former USSR & 0.0 & 0.0 & 0.0 & 0.0 & 2.9 & 4.5 \\
\hline V-197 & VIC 35/89 & V. dalmatica & Bulgaria & 0.0 & 0.0 & 0.0 & 0.0 & 1.1 & 2.3 \\
\hline $\mathrm{V}-282$ & VGd 3 & V. grandiflora & Germany & 0.0 & 0.0 & 0.0 & 11.9 & 0.0 & 3.2 \\
\hline V-52 & PI 183100 & V. hirsuta & Australia & 0.0 & 0.0 & 0.0 & 40.8 & 9.9 & 26.8 \\
\hline V-56 & PI 422499 & $V$. hirsuta & Germany & 0.0 & 0.0 & 6.8 & 51.9 & 16.3 & 23.5 \\
\hline $\mathrm{V}-214$ & VIC 784/74 & V. hirsuta & Ethiopia & 0.0 & 0.0 & 0.0 & 11.1 & 0.0 & 1.1 \\
\hline V-215 & VIC 727/79 & $V$. hirsuta & United Kingdom & 0.0 & 0.0 & 5.6 & 11.2 & 9.1 & 17.2 \\
\hline V-284 & VHy 10 & V. hybrida & Turkey & 0.0 & 14.9 & 0.0 & 3.7 & 0.0 & 0.0 \\
\hline V-9 & PI 249922 & $V$. lutea & Portugal & 0.0 & 0.0 & 10.1 & 37.9 & 15.3 & 27.1 \\
\hline V-109 & VIC $312 / 77$ & V. lutea & Greece & 0.0 & 0.0 & 0.0 & 0.0 & 0.0 & 0.0 \\
\hline $\mathrm{V}-235$ & VIC 68/83 & $V$. megalotropis & Former USSR & 0.0 & 0.0 & 10.6 & 13.3 & 7.1 & 9.5 \\
\hline V-97 & VIC $475 / 89$ & V. melanops var. loiseani & France & 0.0 & 0.0 & 6.7 & 10.9 & 5.2 & 12.6 \\
\hline V-98 & VIC 474/78 & V. melanops var. melanops & France & 0.0 & 0.0 & 19.9 & 47.5 & 14.5 & 27.7 \\
\hline $\mathrm{V}-220$ & VIC 831/80 & V. michauxii & Armenia & 0.0 & 0.0 & 4.8 & 19.4 & 2.8 & 2.8 \\
\hline $\mathrm{V}-257$ & VIC 746/79 & V. michauxii & Former USSR & 0.0 & 0.0 & 6.5 & 31.5 & 3.6 & 7.3 \\
\hline $\mathrm{V}-259$ & VIC 606/78 & $\begin{array}{l}V . \text { monantha subsp. } \\
\text { monantha }\end{array}$ & Former USSR & 0.0 & 0.0 & 14.0 & 39.0 & 6.8 & 16.2 \\
\hline $\mathrm{V}-233$ & VIC 66/86 & $V$. onbrychioides & France & 0.0 & 0.0 & 3.8 & 4.7 & 2.1 & 4.3 \\
\hline $\mathrm{V}-35$ & PI 388825 & $V$. palaestina & Cyprus & 0.0 & 0.0 & 2.5 & 3.8 & 3.2 & 7.2 \\
\hline V-37 & PI 393824 & $V \cdot$ peregrina & Canada & 0.0 & 0.0 & 4.4 & 34.4 & 5.1 & 7.8 \\
\hline$V-44$ & PI 420425 & $V$. peregrina & Spain & 0.0 & 0.0 & 0.0 & 3.8 & 0.0 & 0.5 \\
\hline $\mathrm{V}-45$ & PI 420424 & $V \cdot$ peregrina & Spain & 0.0 & 27.8 & 0.0 & 0.0 & 1.6 & 3.0 \\
\hline V-104 & VIC 315/79 & $V$. peregrina & Turkey & 0.0 & 0.0 & 8.1 & 43.1 & 10.6 & 23.9 \\
\hline V-105 & VIC 657/79 & $V$. peregrina & Australia & 0.0 & 0.0 & 0.0 & 0.0 & 6.0 & 10.0 \\
\hline V-106 & VIC 765/79 & $V$. peregrina & Former USSR & 0.0 & 0.0 & 6.1 & 11.1 & 9.7 & 16.2 \\
\hline V-41 & PI 393825 & $\begin{array}{l}\text { V. sativa subsp. } \\
\text { amphicarpa }\end{array}$ & Canada & 0.0 & 3.5 & 7.4 & 26.8 & 4.0 & 6.1 \\
\hline V-192 & VIC $21 / 79$ & V. tennifolia & Sweden & 0.0 & 0.0 & 1.0 & 4.3 & 0.0 & 3.8 \\
\hline V-193 & VIC $16 / 79$ & V. tennifolia & Former USSR & 0.0 & 0.0 & 0.0 & 0.0 & 1.1 & 2.8 \\
\hline V-194 & VIC 22/89 & V. tennifolia & Former USSR & 0.0 & 0.0 & 0.0 & 0.0 & 0.0 & 0.0 \\
\hline $\mathrm{V}-128$ & VIC 896/82 & $V$. tetrasperma & Former USSR & 0.0 & 0.0 & 4.5 & 6.1 & 2.1 & 6.0 \\
\hline V-133 & VIC 637/74 & V. villosa subsp. eriocarpa & Greece & 0.0 & 2.6 & 3.0 & 13.01 & 26.8 & 45.6 \\
\hline Prothabon & $\ldots$ & $V \cdot f a b a$ & $\ldots$ & $100(6.5)$ & $100(21.1)$ & $100(10.3)$ & $100(21.5)$ & $100(9.8)$ & $100(17.2)$ \\
\hline SE & $\ldots$ & $\ldots$ & $\ldots$ & $\ldots$ & $\ldots$ & 3.25 & 8.93 & 5.89 & 7.86 \\
\hline
\end{tabular}

${ }^{\mathrm{z}}$ Data expressed as the percentage of the number of broomrape plants per the susceptible check, faba bean cv. Prothabon (=100\%). Real values for Prothabon in parentheses. Total $=$ emerged shoots plus nonemerged broomrape attachments; $\mathrm{SE}=$ standard error. 
check induced $53 \%$ of viable seed to germinate, whereas the induction ranged from 0 to $33 \%$ in the Vicia accessions. The second mechanism was a restricted establishment of germinated seed. This was observed only on some accessions (V-52 of $V$. hirsuta, V-133 of $V$. villosa, and V-193 of V. tennifolia) in which only 0 to $18 \%$ of the germinated seed successfully formed tubercles on the host roots, compared with $34 \%$ in the susceptible pea check. Occasionally, necrotic lesions could be observed surrounding the contact points of the broomrape radicle with the host roots, but this was not quantified.

\section{DISCUSSION}

Vetch species (Vicia spp. other than $V$. $f a b a)$ are important forage legumes that suffer from crenate broomrape infection. Because most of the recommended control methods have not been successful, the use of resistant cultivars seems to be the most desirable solution. An alternative method to reduce the amount of broomrape seed in the soil is the use of trap crops. These are resistant plants that stimulate the germination of $O$. crenata seed but restrict their establishment. In this regard, nonlegume crops, such as flax, basil, and coriander (16), as well as the legumes $V$. villosa subsp. dasycarpa and V. narbonensis (15), have been suggested to reduce the amount of broomrape seed in the soil. The resistant accessions V-37 of $V$. peregrina, V-52 of $V$. hirsuta, and V-133 of V. villosa induced relatively high levels of broomrape seed germination but suffered little infection; therefore, they might be exploited as trap crops to reduce the seed bank in the soil.
Resistance to crenate broomrape is scarce and of complex nature in faba bean, lentil, and pea, making breeding for broomrape resistance a difficult task (14). In the present study, several phenotypes associated with resistance have been detected that might be combined in a single cultivar. The first one is avoidance due to low induction of germination of the

Table 4. Number of broomrape attachments, proportion of germinated Orobanche crenata seed, and percentage of broomrape radicles established in the host root for nine accessions in mini-rhizotron trials $^{\mathrm{y}}$

\begin{tabular}{llccc}
\hline Accession & \multicolumn{1}{c}{ Species } & $\begin{array}{c}\text { No. of broomrape } \\
\text { attachments/host plant }\end{array}$ & $\begin{array}{c}\text { O. crenata seed } \\
\text { germinated }(\%)\end{array}$ & $\begin{array}{c}\text { O. crenata radicles } \\
\text { established }(\%)^{\mathbf{z}}\end{array}$ \\
\hline Messire & Pisum sativum & $26.4 \mathrm{a}$ & $53.2 \mathrm{a}$ & $33.7 \mathrm{ab}$ \\
Prothabon & Vicia faba & nd & $37.6 \mathrm{~b}$ & $21.1 \mathrm{c}$ \\
V-196 & V. dalmatica & $0 \mathrm{e}$ & $0 \mathrm{~g}$ & $\ldots$ \\
V-52 & V. hirsuta & $4.2 \mathrm{~d}$ & $21.7 \mathrm{~cd}$ & $18.2 \mathrm{c}$ \\
V-259 & V. monantha & $14.2 \mathrm{bc}$ & $19.3 \mathrm{de}$ & $40.5 \mathrm{a}$ \\
V-37 & V. peregrina & $10.8 \mathrm{c}$ & $20.8 \mathrm{~cd}$ & $36.5 \mathrm{ab}$ \\
V-41 & V. sativa & $14.6 \mathrm{bc}$ & $32.9 \mathrm{bc}$ & $26.9 \mathrm{bc}$ \\
V-246 & V. serratifolia & $16.6 \mathrm{~b}$ & $24.1 \mathrm{bcd}$ & $38.3 \mathrm{ab}$ \\
V-193 & V. tennifolia & $0 \mathrm{e}$ & $4.3 \mathrm{f}$ & $0 \mathrm{e}$ \\
V-128 & V. tetrasperma & $4.8 \mathrm{~d}$ & $9.3 \mathrm{e}$ & $36.9 \mathrm{ab}$ \\
V-133 & V. villosa & $2 \mathrm{de}$ & $19.2 \mathrm{de}$ & $7.7 \mathrm{~d}$ \\
\hline
\end{tabular}

y Percentage of broomrape seed germinated and percentage of established radicles were recorded after 30 days of mini-rhizotrons incubation. Number of broomrape attachments was recorded 50 days later. Data with the same letter per column are not significantly different (Duncan's test, $P<0.05$ ); nd $=$ non determined

${ }^{\mathrm{z}}$ Percentage of those germinated seed contacting the plant root that successfully established a tubercle.

Table 3. Number of Orobanche crenata attachments recorded per plant in plot trial of 37 Vicia accessions $^{\mathrm{x}}$

\begin{tabular}{|c|c|c|c|c|c|c|c|}
\hline \multirow[b]{2}{*}{ Accession } & \multirow[b]{2}{*}{ Species } & \multirow[b]{2}{*}{ Total $^{\mathbf{z}}$} & \multicolumn{5}{|c|}{ Developmental stage of the attachments ${ }^{y}$} \\
\hline & & & S1 & S2 & $\mathbf{S 3}$ & S4 & S5 \\
\hline Messire & Pisum sativum & $17.1 \mathrm{a}$ & 4.2 & 4.8 & 2.9 & 4.0 & 1.2 \\
\hline Protabon & Vicia faba & $16.7 \mathrm{a}$ & 5.3 & 5.0 & 2.8 & 2.5 & 1.1 \\
\hline V-155 & V. benghalensis & $1.0 \mathrm{de}$ & 0.8 & 0.2 & 0.0 & 0.0 & 0.0 \\
\hline V-163 & V. cordata & $1.0 \mathrm{de}$ & 0.4 & 0.3 & 0.2 & 0.1 & 0.0 \\
\hline V-190 & V. cracca var. cracca & $1.9 \mathrm{cde}$ & 1.2 & 0.3 & 0.2 & 0.2 & 0.0 \\
\hline V-196 & $V$. dalmatica & $1.4 \mathrm{cde}$ & 0.8 & 0.4 & 0.1 & 0.1 & 0.0 \\
\hline V-197 & V. dalmatica & $1.4 \mathrm{cde}$ & 0.3 & 0.2 & 0.7 & 0.2 & 0.0 \\
\hline $\mathrm{V}-282$ & $V$. grandiflora & $6.9 \mathrm{~b}$ & 1.9 & 2.6 & 1.0 & 1.4 & 0.0 \\
\hline V-52 & $V$. hirsuta & $2.6 \mathrm{cde}$ & 1.2 & 1.0 & 0.3 & 0.1 & 0.0 \\
\hline $\mathrm{V}-214$ & $V$. hirsuta & $0.9 \mathrm{de}$ & 0.2 & 0.3 & 0.1 & 0.3 & 0.0 \\
\hline V-215 & $V$. hirsuta & $8.2 \mathrm{~b}$ & 2.6 & 1.6 & 1.9 & 2.0 & 0.1 \\
\hline V-284 & V. hybrida & $0.9 \mathrm{de}$ & 0.7 & 0.2 & 0.0 & 0.0 & 0.0 \\
\hline V-9 & $V$. lutea & $1.5 \mathrm{cde}$ & 0.8 & 0.4 & 0.3 & 0.0 & 0.0 \\
\hline V-109 & V. lutea & $0.5 \mathrm{e}$ & 0.5 & 0.0 & 0.0 & 0.0 & 0.0 \\
\hline $\mathrm{V}-235$ & V. megalotropis & $4.3 \mathrm{bcd}$ & 0.9 & 0.9 & 1.0 & 1.5 & 0.0 \\
\hline V-97 & V. melanops var. loiseani & $1.1 \mathrm{cde}$ & 0.2 & 0.6 & 0.3 & 0.0 & 0.0 \\
\hline V-257 & V. michauxii & $2.3 \mathrm{cde}$ & 0.6 & 1.0 & 0.4 & 0.3 & 0.0 \\
\hline V-220 & V. michauxii & $1.2 \mathrm{cde}$ & 0.4 & 0.5 & 0.0 & 0.3 & 0.0 \\
\hline $\mathrm{V}-259$ & V. monantha ssp. monantha & $0.9 \mathrm{de}$ & 0.6 & 0.3 & 0.0 & 0.0 & 0.0 \\
\hline V-233 & V. onbrychioides & $1.2 \mathrm{cde}$ & 0.1 & 0.7 & 0.4 & 0.0 & 0.0 \\
\hline $\mathrm{V}-35$ & $V \cdot$ palaestina & $2.4 \mathrm{cde}$ & 0.7 & 0.1 & 0.4 & 1.2 & 0.0 \\
\hline V-106 & V. peregrina & $4.6 \mathrm{bc}$ & 1.0 & 1.8 & 1.0 & 0.8 & 0.0 \\
\hline V-104 & V. peregrina & $2.6 \mathrm{cde}$ & 0.9 & 0.6 & 0.6 & 0.5 & 0.0 \\
\hline V-105 & V. peregrina & $1.9 \mathrm{cde}$ & 0.6 & 0.9 & 0.3 & 0.1 & 0.0 \\
\hline V-44 & $V$. peregrina & $1.6 \mathrm{cde}$ & 0.6 & 0.7 & 0.0 & 0.3 & 0.0 \\
\hline $\mathrm{V}-45$ & $V$. peregrina & $1.4 \mathrm{cde}$ & 0.7 & 0.4 & 0.2 & 0.1 & 0.0 \\
\hline V-37 & $V$. peregrina & $1.2 \mathrm{cde}$ & 0.6 & 0.6 & 0.0 & 0.0 & 0.0 \\
\hline V-41 & V. sativa ssp. amphicarpa & $1.1 \mathrm{cde}$ & 0.6 & 0.1 & 0.1 & 0.2 & 0.1 \\
\hline V-194 & V. tennifolia & $2.5 \mathrm{cde}$ & 2.0 & 0.0 & 0.5 & 0.0 & 0.0 \\
\hline V-193 & V. tennifolia & $0.9 \mathrm{de}$ & 0.4 & 0.2 & 0.2 & 0.1 & 0.0 \\
\hline V-192 & V. tennifolia & $0.7 \mathrm{e}$ & 0.2 & 0.1 & 0.2 & 0.2 & 0.0 \\
\hline $\mathrm{V}-128$ & $V$. tetrasperma & $1.1 \mathrm{cde}$ & 0.4 & 0.6 & 0.1 & 0.0 & 0.0 \\
\hline V-133 & $V$. villosa ssp. eriocarpa & $0.7 \mathrm{e}$ & 0.4 & 0.1 & 0.0 & 0.2 & 0.0 \\
\hline
\end{tabular}

${ }^{\mathrm{x}}$ Data collected at plant maturity, starting 90 days after sowing.

${ }^{y}$ Developmental stage scored according to the Ter Borg et al. (18) scale, where $\mathrm{S} 1=$ small tubercle, 1 to $3 \mathrm{~mm} ; \mathrm{S} 2=$ crown roots start to develop; $\mathrm{S} 3=$ bud $\leq$ $1 \mathrm{~cm} ; \mathrm{S} 4=$ first development of spike below ground surface; and S5 = emergence of spike.

${ }^{\mathrm{z}}$ Data with the same letter per column are not significantly different (Duncan's test, $P<0.05$ ). 
broomrape seed. A restricted induction of broomrape germination was observed in almost all the accessions studied (Table 4). Similarly, low induction of germination has been found in sorghum against Striga hermonthica, and has been exploited successfully in sorghum breeding (5). Low induction of Orobanche seed germination also has been suggested to occur in chickpea (12) as well as in Arabidopsis thaliana (20) and Medicago truncatula (10). Low induction of broomrape seed germination was considered rare in $V$. faba $(6,18,19)$ and V. atropurpurea (3).

A second phenotype that was observed in this study is the limited establishment of broomrape radicles in contact with host roots. This was observed in accessions V52 of V. hirsuta, V-133 of V. villosa, and V193 of $V$. tennifolia. More research is needed to define the stage at which this putative mechanism of resistance acts. It could be a physical barrier to host tissue penetration (21), or it could involve encapsulation of the penetrated radicle, or necrosis (22). In these accessions, we also found lower levels of germination than in the susceptible check. Other accessions studied in the mini-rhizotrons trial (V-37 of $V$. peregrina, $\mathrm{V}-128$ of $V$. tetrasperma, and V259 of $V$. monantha) showed levels of resistance to germination but not to establishment.

A third phenotype observed in some of the accessions was the limited development of established tubercles. This was evident in accessions V-37 of $V$. peregrina and V-259 of $V$. monantha, where limited emergence of broomrape shoots occurred under field conditions, even when they had high numbers of nonemerged shoots. Furthermore, in pot experiments, all observed tubercles were at an early stage of development $(\mathrm{S} \leq 3)$. The few tubercles established did not grow further even when they had little competition among them. In contrast, other lines, such as V-35 of $V$. palaestina, V-214 of V. hirsuta, and V-235 of $V$. megalotropis, displayed a high ratio of developed/nondeveloped broomrape tubercles in pot experiments, indicating that growth of successfully established tubercles $(S>4)$ was not restricted. In these accessions, the emerged/nonemerged ratio was even higher than in both susceptible checks and can be explained by the lower competition for nutrients among the few established tubercles.

Hypersensitive-like necrosis has been described in faba bean (22) and chickpea (12) against $O$. crenata. Necrotic lesions around the penetrating parasitic radicle have been reported as an important component of resistance in purple vetch $(V$. atropurpurea) against $O$. aegyptiaca (4). Recent anatomical studies showed that the necrotic response observed in chickpea against $O$. crenata does not correspond with the death of host cells in contact with the parasite, but to blocking and death of the penetration structures of the parasite (12). This hypersensitive-like reaction occasionally was observed in the accessions of Vicia studied here, but it was considered a rare event and was not quantified.

In the present work, new sources of resistance to crenate broomrape have been identified in several species of Vicia. Resistance is a multistage process, where the final number of emerged shoots is the consequence of attempts by the parasite to overcome a sequence of defense reactions. Although this sort of resistance (11) is more difficult to manipulate in breeding programs, it might be durable once combined in a single cultivar. This may be facilitated by the use of in vitro screening methods and marker-aided selection for components of resistance.

\section{ACKNOWLEDGMENTS}

We thank A. Moral and R. Cantarero for technical assistance.

\section{LITERATURE CITED}

1. Cubero, J. I., Pieterse, A. H., Khalil, S. A., and Sauerborn, J. 1994. Screening techniques and sources of resistance to parasitic angiosperms. Euphytica 73:51-58.

2. Gil, J., Martín, L. M., and Cubero, J. I. 1987. Genetics of resistance in Vicia sativa L. to Orobanche crenata Forsk. Plant Breed. 99:134-143.

3. Goldwasser, Y., Kleifeld, Y., Plakhine, D., and Rubin, B. 1997. Variation in vetch (Vicia spp.) response to Orobanche aegyptiaca. Weed Sci. 45:756-762.

4. Goldwasser, Y., Plakhine, D., Kleifeld, Y., Zamski, E., and Rubin, B. 2000. The differential susceptibility of vetch (Vicia spp.) to Orobanche aegyptiaca: anatomical studies. Ann. Bot. 85:257-262

5. Haussman, B. I. G., Hess, D. E., Omanya, G. O., Reddy, B. V. S., Welz, H. G., and Geiger, H. H. 2001. Major and minor genes for stimulation of Striga hermonthica seed germination in sorghum, and interaction with different Striga population. Crop Sci. 41:1507-1512

6. Khalaf, K. A., and El-Bastawesy, F. I. 1989. Some studies on the basis of resistance of Vicia faba cultivar 'Giza 402' to Orobanche crenata parasitism. FABIS Newsl. 25:5-9.

7. Linke, K. H., Abd El-Monein, A. M., and Saxena, M. C. 1993. Variation in resistance of some forage legumes species to Orobanche crenata Forsk. Field Crops Res. 32:277-285.

8. López-Granados, F., and García-Torres, L. 1996. Effects of environmental factors on dormancy and germination of crenate broomrape (Orobanche crenata). Weed Sci. 44:284-289.

9. Parker, C. 1994. Protection of crops against parasitic weeds. Crop Prot. 10:6-22

10. Rodríguez-Conde, M. F., Moreno, M. T., Cubero, J. I., and Rubiales, D. 2004. Characterization of the Orobanche-Medicago trunca- tula system for studying parasite-host interactions. Weed Res. 44:218-223.

11. Rubiales, D. 2003. Resistance against parasitic weeds. New Phytol. 160:455-462.

12. Rubiales, D., Alcántara, C., Pérez-de-Luque, A., and Sillero, J. C. 2003. Characterization of the resistance to Orobanche crenata in chickpea. Weed Sci. 51:702-707.

13. Rubiales, D., Alcántara, C., Pérez-de-Luque, A. Gil, J., and Sillero, J. C. 2003. Infection of chickpea (Cicer arietinum) by crenate broomrape (Orobanche crenata) as influenced by sowing date and weather conditions. Agronomie 23:359-362.

14. Rubiales, D., Sillero, J. C., Román, M. B., Moreno, M. T., Fondevilla, S., Pérez-deLuque, A., Cubero, J. I., Zermane, N., Kharrat, M., and Khalil, S. 2002. Management of broomrape in Mediterranean agriculture. Pages 67-73 in: Legumes: Grain Legumes in the Mediterranean Agriculture. Association Européenne de recherche sur les Protéagineux, Paris, France.

15. Saxena, M. C., Linke, K. H., and Sauerborn, J. 1994. Integrated control of Orobanche in coolseason food legumes. Pages 419-431 in: Biology and Management of Orobanche, Proc. 3rd Int. Workshop on Orobanche and Related Striga Research. A. H. Pieterse, J. A. C. Verkleij, and S. J. Ter Borg, eds. Amsterdam.

16. Schnell, H., Linke, K. H., and Sauerborn, J. 1994. Trap cropping and its effect on yield and Orobanche crenata Forsk. infestation on following pea (Pisum sativum L.) crops. Trop. Sci. 34:306-314.

17. Sillero, J. C., Rubiales, D., and Moreno, M. T. 1999. New sources of resistance to broomrape (Orobanche crenata) in a collection of Vicia species. Pages 45-54 in: Resistance to $\mathrm{OrO}^{-}$ banche: The State of the Art. J. I. Cubero, M. T. Moreno, D. Rubiales, and J. C. Sillero, eds. Junta de Andalucía, Seville, Spain.

18. Ter Borg, S. J., Willemsen, A., Khalil, S. A., Saber, H. A., Verkleij, J. A. C., and Pieterse, A. H. 1994. Field study of the interaction between Orobanche crenata Forsk. and some new lines of Vicia faba L. in Egypt. Crop Prot. 13:611616.

19. Van Woerden, I. C., Van Ast, A., Zaitoun, F. M. F., and Ter Borg, S. J. 1994. Root exudates of resistant faba bean cultivars are strong stimulants of broomrape germination. Pages 169172 in: Biology and Management of Orobanche, Proc. 3rd Int. Workshop on Orobanche and Related Striga Research. A. H. Pieterse, J. A. C. Verkleij, and S. J. Ter Borg, eds. Amsterdam.

20. Westwood, J. H. 2000. Characterization of the Orobanche-Arabidopsis system for studying parasite-host interactions. Weed Sci. 48:742748.

21. Zaitoun, F. M. F., Al-Menoufi, O. A., and Weber, H. C. 1991. Mechanisms of tolerance and susceptibility of three Vicia faba varieties to the infection with Orobanche crenata. Pages 195-207 in: Proc. 5th Int. Symp. Parasitic Weeds. J. K. Ransom, L. J. Musselman, A. D. Worsham, and C. Parker, eds. Nairobi, Kenya.

22. Zaitoun, F. M. F., and Ter Borg, S. J. 1994. Resistance against Orobanche crenata in Egyptian and Spanish faba beans. Pages 264275 in: Biology and Management of Orobanche, Proc. 3rd Int. Workshop on Orobanche and Related Striga Research. A. H. Pieterse, J. A. C. Verkleij, and S. J. Ter Borg, eds. Amsterdam. 